\title{
Perfil de restrição de um fragmento do gene da hemaglutinina amplificado pela RT-PCR a partir de estirpes vacinais e selvagens do vírus da cinomose canina
}

\author{
[Restriction pattern of a hemagglutinin gene amplified by RT-PCR from vaccine strains and wild-type canine \\ distemper virus] \\ F.J. Negrão ${ }^{1}$, S.H. Wosiacki $^{1}$, A.A. Alfieri ${ }^{2,3^{*}}$, A.F. Alfieri ${ }^{2}$ \\ ${ }^{1}$ Aluno de pós-graduação - UEL - Londrina, PR \\ ${ }^{2}$ Departamento de Medicina Veterinária Preventiva - CCA-UEL \\ Caixa Postal 6001 \\ 86051-990 - Londrina, PR \\ ${ }^{3}$ Bolsista do $\mathrm{CNPq}$ \\ RESUMO
}

\begin{abstract}
Fragmentos com 721 pares de bases do gene da hemaglutinina $(\mathrm{H})$ do vírus da cinomose canina (CDV), amplificados pela RT-PCR a partir de três estirpes vacinais (Snyder Hill, Onderstepoort e Rockborn) e de 27 amostras de campo, provenientes de cães com cinomose, foram clivados com as endonucleases Hinf I and Rsa I. A seleção das enzimas foi realizada por meio de análises in silico de seqüências do CDV depositadas em bases públicas de dados. Tanto as estirpes vacinais quanto as amostras selvagens do CDV apresentaram com a enzima Hinf I o mesmo perfil de restrição, confirmando a identidade do fragmento amplificado pela RT-PCR, uma vez que todas as estirpes com seqüências disponíveis (GenBank) têm sítios de restrição para essa enzima nas mesmas posições. O perfil de restrição das estirpes vacinais Snyder Hill e Onderstepoort, que diferem entre si, foi confirmado com a enzima Rsa I que também clivou a estirpe Rockborn nas mesmas posições que a estirpe Snyder Hill. Todas as 27 amostras de campo do CDV apresentaram com a enzima Rsa I o mesmo perfil de restrição, indicando conservar os mesmos sítios de restrição para essa enzima. O perfil das amostras de campo foi diferente daquele obtido nas três estirpes vacinais. Os perfis de restrição do gene que codifica a hemaglutinina do CDV, gerados pela enzima $R s a$ I, sugerem diferenças moleculares entre as estirpes vacinais e as selvagens circulantes na região norte do estado do Paraná e abrem a perspectiva da elaboração de análises moleculares comparativas mais complexas, como o seqüenciamento de todo o gene $\mathrm{H}$, de estirpes do CDV identificadas em diferentes regiões brasileiras.
\end{abstract}

Palavras-chave: cão, cinomose, vírus da cinomose canina, gene H, RT-PCR, RFLP

\begin{abstract}
The restriction fragment length polymorphism (RFLP) assay of a 721 bp fragment from hemagglutinin $(H)$ gene of canine distemper virus (CDV) amplified by RT-PCR was analyzed with Hinf I and Rsa I enzymes. Clinical samples from 27 dogs with natural canine distemper infection, and three vaccine (Snyder Hill, Onderstepoort and Rockborn) CDV strains were analyzed. All RT-PCR amplified product from CDV wild-type and vaccine-strains had the same RFLP pattern with Hinf I enzyme showing the amplicon specificity. The RFLP pattern for CDV vaccine-strains generated with Rsa I enzyme was the expected by in silico analysis. All 27 wild-type CDV strains present the same Rsa I enzyme RFLP pattern that was different from vaccine-strains pattern, suggesting molecular differences between vaccine-strains and wild-type of CDV from dogs population in North region of Paraná State/Brazil. These results open the perspectives of the accomplishment of comparative molecular analysis, such as sequencing of the whole gene $H$, of $C D V$ wild-type strains identified in different Brazilian regions.
\end{abstract}

Keywords: dog, canine distemper, canine distemper virus, H gene, RT-PCR, RFLP

Recebido em 13 de abril de 2005

Aceito em 28 de julho de 2005

*Autor para correspondência (corresponding author)

E-mail: alfieri@uel.br

Apoio: CNPq, CAPES, Fundação Araucária (FAP/PR) 


\section{INTRODUÇÃO}

$\mathrm{O}$ vírus da cinomose canina (canine distemper virus - CDV), classificado na família Paramyxoviridae, gênero Morbillivirus (Pringle, 1999), é o agente etiológico da cinomose, considerada uma das principais infecções virais em cães e outros carnívoros (Appel e Summers, 1999). A cinomose é uma doença multissistêmica de evolução aguda, subaguda ou crônica que, além dos sinais clínicos sistêmicos, pode também evoluir para graves sinais neurológicos. Em cães a infecção é altamente contagiosa e pode ocasionar elevadas taxas de letalidade (Tipold, 1995).

A cinomose é de ocorrência mundial (Appel et al., 1994). Em vários países, devido à vacinação regular de grande parte da população canina, a freqüência da doença clínica tem diminuído substancialmente, sendo relatados apenas focos esporádicos (Haas et al., 1997; Moshizuki et al., 1999). No Brasil, a cinomose ainda é endêmica, podendo representar até $6 \%$ de todas as ocorrências clínicas e até $11 \%$ das mortes em cães (Headley e Graça, 2000).

O CDV é um vírus com genoma RNA fita simples, polaridade negativa, constituído por seis genes que codificam $\left(3^{\prime}-5^{\prime}\right)$ as proteínas $\mathrm{N}$ (nucleoproteína), P (fosfoproteína), M (proteína matriz), F (proteína de fusão), $\mathrm{H}$ (hemaglutinina) e L (grande proteína) (Diallo, 1990). Análises moleculares têm demonstrado grande similaridade entre as estirpes do CDV avaliadas e estudos realizados com anticorpos policlonais revelaram, até o momento, apenas um sorotipo viral (Chapuis, 1995; Bolt et al., 1997; Haas et al., 1997).

A proteína $\mathrm{H}$, principal glicoproteína do envelope do CDV, é a que apresenta maior diversidade e, por isso, é a mais adequada para monitorar mudanças genéticas no vírus (Örvell et al., 1990). Análises filogenéticas do gene H mostraram diferenças genéticas entre as estirpes do $\mathrm{CDV}$ provenientes de regiões geográficas distintas (Harder et al., 1996) e também de outros paramyxovírus relacionados, como o vírus da peste bovina e o vírus do sarampo (Chamberlain et al., 1993; Rima et al., 1995). A análise do gene $\mathrm{H}$ do CDV possibilita a organização das estirpes virais em genótipos (Bolt et al., 1997).
Estudos que utilizaram painéis de anticorpos monoclonais, realizados com estirpes vacinais do CDV e estirpes isoladas de casos clínicos, também demonstraram grande variação antigênica na proteína $\mathrm{H}$ e maior estabilidade nas proteínas F e P (Haas et al., 1999; Mochizuki et al., 1999).

Relatos de falhas vacinais na profilaxia da cinomose canina são freqüentes (Morrel, 1994; Haas et al., 1997). Uma gama de fatores, incluindo aqueles inerentes ao hospedeiro e ao antígeno, pode ser responsável pela ocorrência de cinomose em cães vacinados. As estirpes incluídas na grande maioria das vacinas atenuadas utilizadas em todo o mundo, inclusive no Brasil, surgiram no início de 1960 (Chappuis, 1995). Os estudos com o objetivo de caracterização antigênica e molecular de estirpes selvagens e vacinais do $\mathrm{CDV}$ ainda são realizados de forma esporádica em todo o mundo (Moshizuki et al., 1999; Bolt et al., 1997; Haas et al., 1997).

O presente trabalho teve como objetivo avaliar o perfil de restrição de um fragmento com 721 pares de base (pb) do cDNA do gene $\mathrm{H}$ do CDV, amplificado por meio da reação em cadeia da polimerase precedida de transcrição reversa (RTPCR), realizada a partir de material biológico obtido de cães com diferentes sinais clínicos de cinomose.

\section{MATERIAL E MÉTODOS}

A estirpe Rockborn do CDV foi amplificada em células MDCK (Madin Darby canine kidney), mantidas em meio mínimo essencial Eagle's ${ }^{1}$, conforme procedimento padrão. As estirpes Snyder Hill e Onderstepoort, sob a forma inativada e liofilizada, foram gentilmente cedidas por laboratórios produtores de vacinas comerciais.

Estirpes vacinais do parvovírus canino, coronavírus canino, parainfluenzavírus canino e do adenovírus canino, presentes em vacinas comerciais, foram utilizadas na avaliação da especificidade da RT-PCR.

\footnotetext{
${ }^{1}$ Invitrogen $^{\mathrm{TM}}$, Life Technologies, EUA
} 
Foram selecionados 27 cães provenientes da região norte do estado Paraná, atendidos em hospital escola veterinário entre maio e novembro de 2003. Como critério de inclusão utilizou-se a presença de sinais clínicos compatíveis com a cinomose canina e o resultado positivo na técnica da RT-PCR para a amplificação do gene $\mathrm{N}$ do $\mathrm{CDV}$ utilizando os oligonucleotídeos iniciadores (primers) CDV1 (5'aca gga ttg ctg agg acc tat 3 ' nt 769-789) e CDV2 (5'caa gat aac cat gta cgg tgc 3' nt 10551035) (Frisk et al., 1999), realizada de acordo com as modificações descritas por Gebara et al. $(2004 \mathrm{a} / \mathrm{b})$.

Os animais foram subdivididos em três grupos. No grupo A, foram incluídos 10 cães que apresentavam um ou mais sinais clínicos entéricos e/ou respiratórios comuns à forma sistêmica da cinomose canina. $\mathrm{O}$ grupo $\mathrm{B}$, foi constituído por oito animais com manifestação clínica compatível com a forma neurológica da cinomose destacando-se os sinais de mioclonia e tremores musculares. No grupo $\mathrm{C}$, foram incluídos nove cães que apresentavam, simultaneamente, os sinais clínicos encontrados nas formas sistêmica e neurológica da cinomose canina.

A especificidade da RT-PCR na detecção do gene $\mathrm{H}$ do $\mathrm{CDV}$ em amostras clínicas provenientes de cães foi avaliada em um grupo (D), constituído por cinco animais assintomáticos e negativos na RT-PCR para o gene $\mathrm{N}$ do CDV. Os cães incluídos nesse grupo eram animais saudáveis, de procedência definida, e que vieram a óbito devido a fraturas múltiplas ocasionadas por atropelamento.

Todas as amostras biológicas incluídas nesse estudo foram obtidas de forma indolor $\mathrm{e}$ respeitando as normas de bem-estar e conforto dos animais. De todos os animais colheram-se $2 \mathrm{ml} \mathrm{de}$ urina, por meio de cistocentese ou sondagem uretrovesical, e $3 \mathrm{ml}$ de sangue com anticoagulante por venopunção. Dos animais incluídos nos grupos B e C, sob anestesia geral, ainda foram colhidos 1 a $2 \mathrm{ml}$ de líquido cefalorraquidiano, por meio da punção do espaço subaracnóide através da cisterna magna. Naqueles animais cujos proprietários optaram pela eutanásia, que foi realizada sob anestesia geral precedida de tranqüilização, foram também colhidos fragmentos do sistema nervoso central (SNC) durante a necropsia. O processamento inicial de todas as amostras foi realizado conforme descrito por Saito et al (2005).

Alíquotas de $300 \mu \mathrm{l}$ das amostras biológicas foram submetidas à extração do RNA pelo método da sílica/isotiocianato de guanidina (Bomm et al., 1990). Em todos os procedimentos de extração do RNA foram incluídas alíquotas de água ultrapura ${ }^{2}$ autoclavada como controle negativo e a estirpe Rockborn do CDV como controle positivo.

Para a amplificação do gene $\mathrm{H}$ do $\mathrm{CDV}$, os primers NAW1 (+) 5' atc ggc agc aaa ycc tat c 3', nt 7570 , e NAW2 (-) 5' tgg caa ctg tcy tcc tcc $3^{\text {' }}$ nt 8291, foram desenhados com o auxilio do programa Gene Runner 3,05 (www.generunner.com), utilizando como base o genoma da estirpe Onderstepoort (GenBank, número de acesso AF378705). Para a seleção da região a ser amplificada, utilizaram-se as seqüências conhecidas do gene $\mathrm{H}$ dos Morbillivirus de cães, carnívoros não-domésticos, roedores e mamíferos marinhos, que foram analisadas com os softwares ClustalW (http://www.ebi.ac.uk/clustalw/) e BLAST (www.ncbi.nlm.nih.gov) (Altschul et al., 1990).

Para a transcrição reversa (RT), foram utilizados $9 \mu 1$ do RNA extraído e 20 pmol do primer NAW1. Após incubação a $70^{\circ} \mathrm{C}$ por $10 \mathrm{~min}$, seguida de imersão em gelo, adicionou-se a solução RT-MIX constituída por $0,8 \mathrm{mM} \mathrm{dNTP}^{1}$, 1 x PCR buffer (20mM Tris- $\mathrm{HCl} \mathrm{pH} 8,4 ; 50 \mathrm{mM} \mathrm{KCl}), 1,5 \mathrm{mM}$ $\mathrm{MgCl}_{2}, 60$ unidades da enzima transcriptase reversa $M-M^{2} V^{1}$ e água ultrapura autoclavada para a obtenção do volume final de $20 \mu \mathrm{l}$. A RT foi realizada a $42^{\circ} \mathrm{C}$ por $30 \mathrm{~min}$ seguida de $7 \mathrm{~min}$ a $70^{\circ} \mathrm{C}$ para inativação da enzima.

Para a PCR foram utilizados $5 \mu 1$ do cDNA e PCRMIX contendo 20pmol de cada primer (NAW1 e NAW2), 0,8mM dNTP, 1 x PCR buffer, 1,5mM $\mathrm{MgCl}_{2}, 2,5$ unidades da enzima Taq DNA polimerase recombinante ${ }^{1}$ e água ultrapura autoclavada para o volume final de $50 \mu \mathrm{l}$.

O processo de amplificação foi realizado em termociclador $^{3}$ programado com as seguintes condições de tempo e temperatura: uma etapa de

\footnotetext{
${ }^{2}$ Milli-Q ${ }^{\circledR}$ plus, Millipore Co., EUA
}

${ }^{3}$ PTC-200, MJ Research Co., EUA. 
$94^{\circ} \mathrm{C} / 1 \mathrm{~min}$, seguida por 40 ciclos de $94^{\circ} \mathrm{C} / 1 \mathrm{~min}$, $54^{\circ} \mathrm{C} / 1 \mathrm{~min}, 72^{\circ} \mathrm{C} / 1 \mathrm{~min}$ e uma etapa de extensão final de $7 \min$ a $72^{\circ} \mathrm{C}$.

Com base na análise das seqüências do gene $\mathrm{H}$ das estirpes do CDV disponíveis no GenBank, realizada com os softwares Gene Runner e ClustalW, foram selecionadas duas enzimas para a clivagem do produto amplificado pela RTPCR. Pela análise in sílico a enzima Hinf $\mathrm{I}^{1}$ apresenta sítios de restrição conservados em todas as estirpes do CDV seqüenciadas até o momento, gerando fragmentos com tamanhos de 320, 250, 77, 69 e 5pb. Essa enzima foi empregada com o objetivo de avaliar a especificidade do produto amplificado. Para a caracterização molecular parcial das estirpes do CDV provenientes de cães com diferentes formas clínicas da doença, foi selecionada a enzima $R s a$ $I^{1}$. No produto amplificado do gene H $(721 \mathrm{pb})$ proveniente da estirpe Snyder Hill, é encontrado um único sítio de clivagem para essa enzima gerando fragmentos com tamanhos de 358 e $363 \mathrm{pb}$. $\mathrm{Na}$ estirpe Onderstepoort são encontrados, nesse mesmo produto, dois sítios de restrição gerando fragmentos com 363, 327 e $31 \mathrm{pb}$. Até o momento ainda não há seqüência disponível, em bases públicas de informação genômica, para o gene $\mathrm{H}$ da estirpe Rockborn do CDV. As endonucleases de restrição Hinf I e Rsa I foram utilizadas de acordo com as instruções do fabricante.

Os produtos amplificados pela RT-PCR e os clivados com enzimas de restrição foram analisados por eletroforese em gel de agarose $2 \%$ em tampão TBE pH $8,4(89 \mathrm{mM}$ Tris; $89 \mathrm{mM}$ ácido bórico; $2 \mathrm{mM}$ EDTA), contendo $0,5 \mu \mathrm{g} / \mathrm{ml}$ de brometo de etídio e visualizados sob luz ultravioleta. As imagens foram capturadas em sistema de fotodocumentação digital ${ }^{4}$.

\section{RESULTADOS E DISCUSSÃO}

A RT-PCR para a amplificação parcial do gene $\mathrm{H}$ do $\mathrm{CDV}$ apresentou resultado positivo em todos os 27 cães com cinomose incluídos nesse estudo. Independentemente $\mathrm{da}$ forma da infecção, sistêmica, neurológica ou a associação de ambas, em pelo menos uma amostra clínica de cada animal foi amplificado o produto com $721 \mathrm{pb}$ (Fig. 1).

Nenhum material biológico utilizado como controle negativo da reação (água ultrapura autoclavada, amostras vacinais de vírus caninos, urina, leucócitos e fragmentos do SNC de cães assintomáticos) foi positivo na RT-PCR, demonstrando a especificidade da técnica (Fig. 2).

O objetivo principal da RT-PCR utilizando primers específicos para o gene $\mathrm{H}$ do $\mathrm{CDV}$ não foi o de diagnóstico. Os resultados descritos anteriormente demonstram a especificidade tanto dos primers quanto da técnica padronizada. Com isso a RT-PCR para a detecção do gene $\mathrm{H}$ do CDV pode ser utilizada como ferramenta adicional para o diagnóstico da cinomose canina.

O CDV apresenta como característica molecular a grande similaridade, observada em reações de seqüenciamento, entre as estirpes isoladas de várias regiões geográficas a partir de diferentes espécies animais com manifestações clínicas distintas. A análise filogenética do gene $\mathrm{H}$ do CDV tem possibilitado a organização das estirpes virais em grupos, independentemente da espécie animal no qual foi isolado, e com nítida distribuição geográfica. Por todos esses fatores o gene $\mathrm{H}$ é o mais indicado para o monitoramento de variações moleculares no CDV (Bolt et al., 1997; Haas et al., 1997, 1999; Moshizuki et al., 1999).

Análises in sílico demonstraram que a região do gene $\mathrm{H}$ amplificada pelos primers NAW1 e NAW2 apresenta homologia média de 97\% entre as estirpes do CDV com seqüências disponíveis no GenBank.

As estirpes Onderstepoort e Rockborn são as mais utilizadas em todo o mundo para a elaboração de vacinas contra o CDV (Mochizuki et al., 1999). A estirpe Snyder Hill, por apresentar grande potencial neurotrópico, é a mais utilizada em experimentos de inoculação intracerebral, tanto em estudos da patogênese viral quanto em desafio pós-vacinal (Slater, 1970). Porém, seqüências para o gene $H$ da estirpe Rockborn ainda não são disponíveis em bases públicas de dados.

\footnotetext{
${ }^{4}$ DC 290, Kodak ${ }^{\circledR}$ Co., EUA.
} 


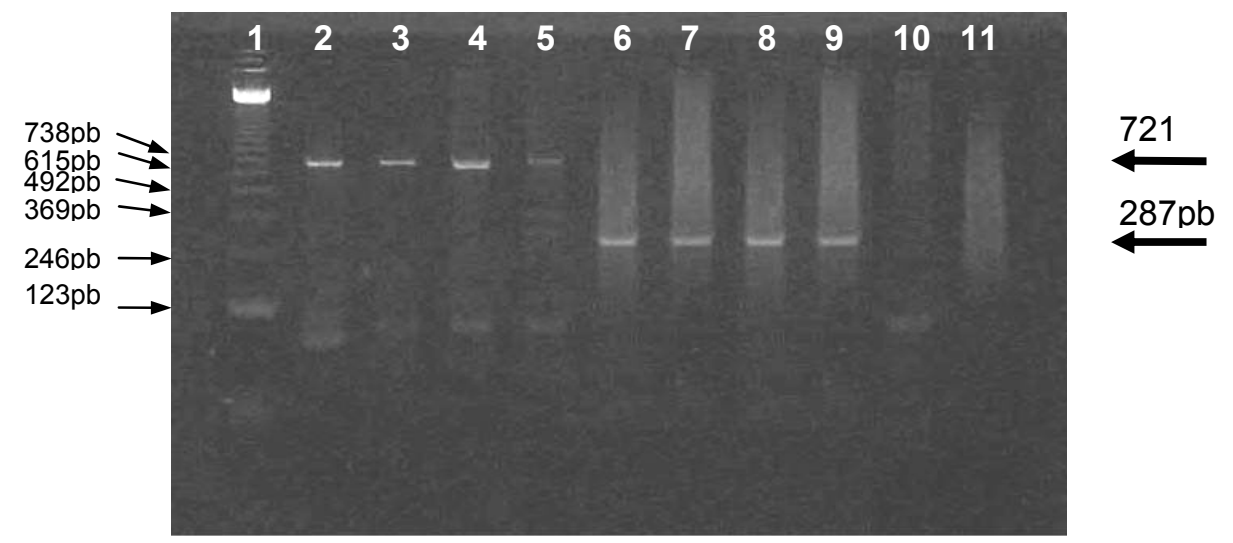

Figura 1. Eletroforese em gel de agarose a $2 \%$ corado com brometo de etídio dos produtos dos genes da hemaglutinina (canaletas 2 a 5) e da nucleoproteína (canaletas 6 a 9) do vírus da cinomose canina, amplificados pela RT-PCR a partir de amostras clínicas provenientes de cães com sinais clínicos de cinomose. Canaleta 1: padrão de tamanho molecular 123pb ladder ${ }^{1}$; Canaletas 2 e 6 : urina; Canaletas 3 e 7: leucócitos; Canaletas 4 e 8: líquor; Canaletas 5 e 9: fragmentos de SNC; Canaletas 10 e 11: controles negativos (água ultrapura estéril) das reações para o gene H (10) e N (11).

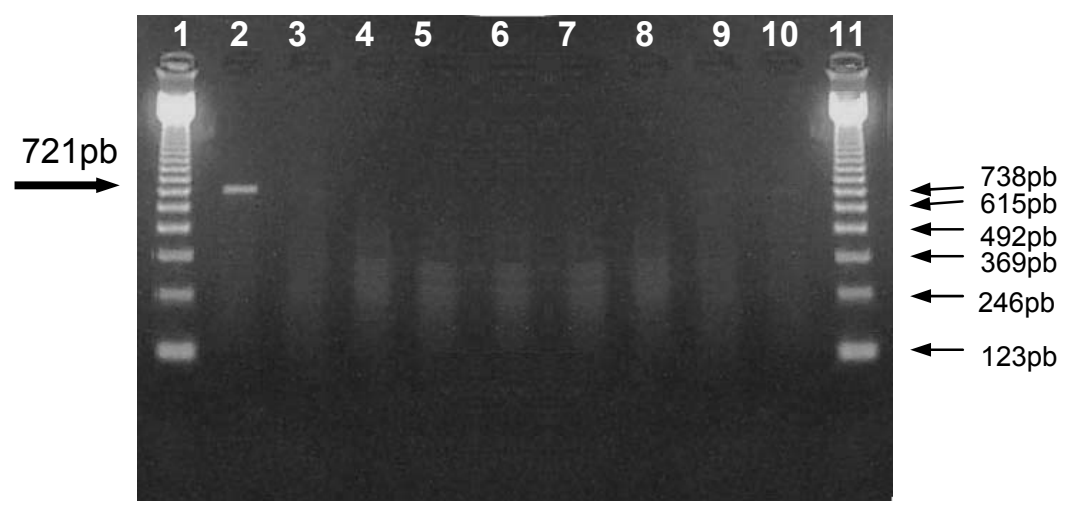

Figura 2. Eletroforese em gel de agarose a $2 \%$ corado com brometo de etídio para a avaliação da especificidade da técnica da RTPCR na deteç̧ão do gene da hemaglutinina do vírus da cinomose canina frente a material genético de outros vírus caninos e amostras clínicas de cães assintomáticos. Canaletas 1 e 11: padrão de tamanho molecular 123pb ladder ; Canaleta 2: estirpe Rockborn do vírus da cinomose canino (controle positivo); Canaletas 3 a 6: estirpes vacinais do parvovírus canino (3), coronavírus canino (4), parainfluenzavírus canino (5) e adenovírus canino (6); Canaletas 7 a 9: urina (7), leucócitos (8) e fragmento do SNC (9) de cães assintomáticos; Canaleta 10: controle negativo da reação (água ultrapura estéril).

A enzima Hinf I clivou todos os produtos amplificados do gene $\mathrm{H}$ nos mesmos sítios. Tanto as estirpes vacinais (Rockborn, Snyder Hill e Onderstepoort) quanto todas as 27 amostras selvagens analisadas apresentaram, com essa enzima, o mesmo perfil de restrição que possibilitou a visualização de fragmentos de aproximadamente 320 e $250 \mathrm{pb}$. Devido às características de porosidade do gel de agarose os fragmentos de pequeno tamanho molecular com 77, 69 e 5pb não puderam ser visualizados. A conservação dos sítios de clivagem para a enzima Hinf I dentro dos genogrupos, observada em todas as estirpes de CDV seqüênciadas até o momento, possibilitou a seleção dessa enzima para a análise da especificidade do produto amplificado. Esse resultado, em que todas as amostras (vacinais e selvagens) apresentaram o mesmo perfil de restrição, ratifica que o produto amplificado é específico do CDV (Fig. 3). 


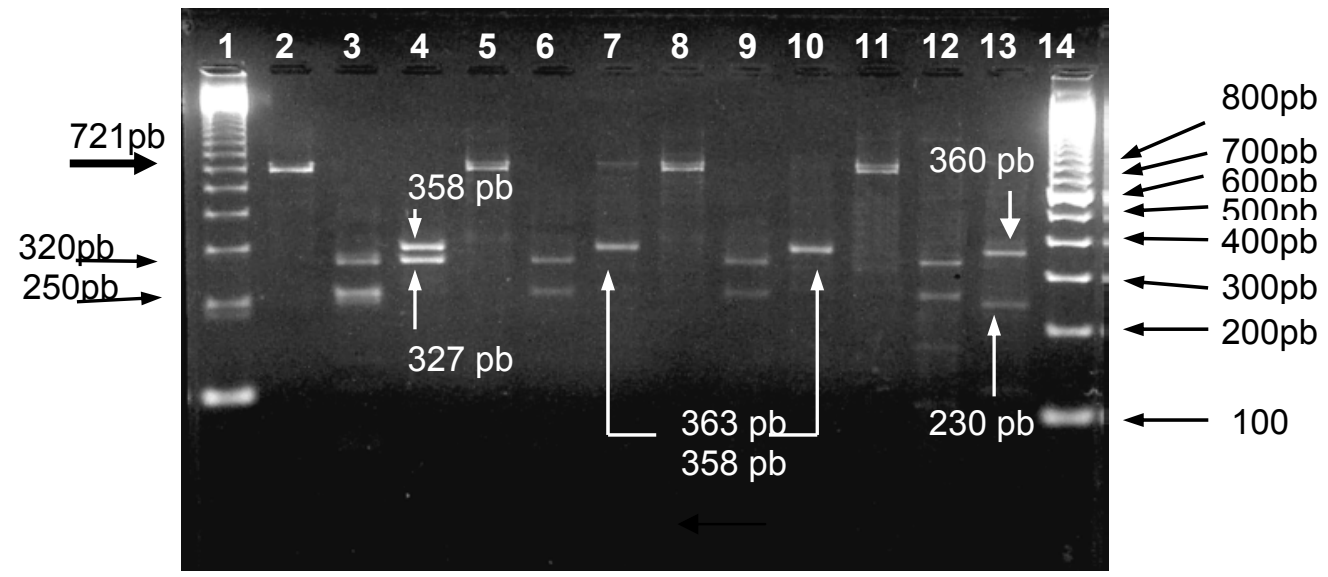

Figura 3. Eletroforese em gel de agarose a $2 \%$ corado com brometo de etídio, dos produtos da amplifícação parcial do gene da hemaglutinina $(\mathrm{H})$ de estirpes vacinal e selvagem do vírus da cinomose canina (CDV), obtidos pela técnica da RT-PCR, e dos fragmentos de cDNA clivados com as enzimas de restrição Hinf I e Rsa I. Canaletas 1 e 14: padrão de tamanho molecular com $123 \mathrm{pb}$ (1) e 100pb (11) ladder $^{1}$; Canaletas 2, 5, 8 e 11: produtos com 721pb do gene $\mathrm{H}$ das estirpes vacinais Onderstepoort (2), Rockborn (5), Snyder Hill (8) e selvagem (11) do CDV; Canaletas 3, 6, 9 e 12: respectivos produtos das canaletas 2, 5, 8 e 11 clivados com a enzima Hinf I; Canaletas 4, 7, 10 e 13: respectivos produtos das canaletas 2, 5, 8 e 11 clivados com a enzima Rsa I.

A clivagem dos produtos da RT-PCR do gene $\mathrm{H}$ da estirpe Onderstepoort com a enzima Rsa I produziu o perfil esperado com dois fragmentos de aproximadamente 327 e $358 \mathrm{pb}$, não sendo possível a visualização do fragmento de $36 \mathrm{pb}$. A clivagem da estirpe Snyder Hill com a enzima Rsa I também produziu o perfil esperado, com fragmentos de 358 e $363 \mathrm{pb}$, que devido à pequena diferença no tamanho molecular $(5 \mathrm{pb})$ co-migraram em gel de agarose.

A estirpe Rockborn, que não tem seqüência genômica disponível para o gene $\mathrm{H}$, ao ser clivada com a enzima $R s a$ I gerou o mesmo perfil da estirpe Snyder Hill. A seqüência do gene H da estirpe Snyder Hill possui alto grau de homologia com as estirpes vacinais, provavelmente devido ao fato de terem sido isoladas na mesma época (Haas et al., 1997).

O perfil de restrição do fragmento com $721 \mathrm{pb}$ com a enzima $R s a$ I de todas das 27 amostras de campo do CDV foi semelhante entre si, porém diferente do observado nas estirpes vacinais. Foram gerados dois fragmentos com aproximadamente 360 e $230 \mathrm{pb}$ que foram facilmente visualizados em gel de agarose corado com brometo de etídio. Os outros fragmentos, que totalizam $111 \mathrm{pb}$, provavelmente de pequenos tamanhos moleculares, não foram visualizados (Fig. 3).
Os perfis de restrição, gerados pelas enzimas Hinf I e Rsa I, foram obtidos a partir de produtos amplificados pela RT-PCR, que foi realizada em amostras clínicas (urina, líquor, leucócitos e fragmentos do SNC) colhidas de cães com sinais clínicos distintos, sugestivos de cinomose, e também com diagnóstico molecular da infecção realizado por meio da detecção do gene $\mathrm{N}$ do CDV. A análise do perfil de restrição de amplicons obtidos pela RT-PCR, realizada diretamente a partir do material clínico, diminui a possibilidade de mutações de ponto que são comuns, particularmente em vírus com genoma RNA, durante o isolamento viral in vitro, devido à adaptação do vírus à célula hospedeira (Bolt et al., 1997).

Os resultados indicaram que os produtos do gene $\mathrm{H}$ do CDV, amplificados a partir das amostras de campo, independentemente dos sinais clínicos apresentados pelos cães (grupos A, B ou C) apresentam sítios de restrição nas mesmas posições. Evidencia-se também que existem diferenças no gene $\mathrm{H}$ das estirpes que determinam doença clínica em cães de nossa região e aquelas que são amplamente utilizadas para a produção de vacinas para o controle $\mathrm{e}$ profilaxia da cinomose canina, particularmente as estirpes Onderstepoort e Rockborn.

A demonstração de que todas as 27 amostras de campo do CDV apresentaram perfil de restrição com a enzima Rsa I diferente das estirpes 
vacinais, descarta a possibilidade de que qualquer uma das amostras amplificadas pudesse ter origem vacinal. Em caso de doença clínica após a vacinação, a análise do segmento de $721 \mathrm{pb}$ do gene $\mathrm{H}$ do $\mathrm{CDV}$ clivado com a enzima $R s a$ I, pode ser utilizada para confirmar ou descartar a possibilidade de reversão da virulência do vírus vacinal.

Estudos complementares fazem-se necessários para avaliar se as diferenças no gene $\mathrm{H}$ do CDV identificadas na análise comparativa entre as estirpes vacinal e de campo, presentes na região Norte do Estado do Paraná, são suficientes para interferir no processo de imunização dos cães contra a cinomose canina. Divergências no perfil de restrição de um produto amplificado sugerem diferenças na seqüência de nucleotídeos entre as estirpes de campo e as vacinais. Porém, ainda não se pode afirmar que essas diferenças possam envolver também diferenças em aminoácidos da proteína $\mathrm{H}$ e, conseqüentemente, alteração na estrutura antigênica da proteína.

No Brasil é freqüente o relato de clínicos veterinários de que cães com esquema regular de vacinação, particularmente aqueles com uma, duas ou até mesmo três doses de vacina, desenvolvem quadros clínicos de cinomose. Falhas vacinais podem ser geradas por múltiplos fatores como interferência de anticorpos passivos, falhas individuais na resposta imune, qualidade, conservação e variabilidade antigênica do imunógeno e infecção anterior à vacinação, entre outros.

A probabilidade de mutações do tipo adição, deleção e substituição de nucleotídeos em vírus como genoma constituído por RNA é bem maior que em vírus DNA. Apenas um sorotipo do CDV é descrito (Pringle, 1999), entretanto, são conhecidas diferenças biológicas entre as estirpes. Há variações nas formas de manifestação clínica da doença, bem como também é passível de infecção uma gama de hospedeiros tais como cães, roedores, carnívoros selvagens e mamíferos aquáticos (Appel e Summers, 1999). Essas diferenças biológicas entre as estirpes do CDV sugerem também a atividade de estirpes virais com diferenças moleculares e/ou antigênicas que, em algumas circunstâncias, podem interferir tanto no diagnóstico quanto na imunoprofilaxia da infecção (Bolt et al., 1997; Haas et al., 1999; Moshizuki et al., 1999).
O monitoramento das características antigênicas e moleculares de estirpes circulantes do CDV é fundamental para o sucesso no controle da infecção. $\mathrm{O}$ gene $\mathrm{H}$, por suas características, é o mais indicado para essa análise e a amplificação a partir do material clínico diminui a possibilidade de mutações de ponto na seqüência de nucleotídeos que ocorrem, com maior freqüência, durante o isolamento in vitro, devido à adaptação do vírus à célula hospedeira (Bolt et al., 1997).

Os resultados obtidos no presente trabalho sugerem que existem diferenças moleculares entre as estirpes vacinais do CDV e aquelas que determinam doença clínica na região Norte do Estado do Paraná. Entretanto, o grau de interferência dessas diferenças nas características antigênicas das estirpes virais que ocasionam a cinomose canina em nossa região precisa ser avaliado. Os resultados desse estudo abrem a perspectiva da elaboração de análises moleculares comparativas mais complexas, particularmente com relação ao seqüenciamento de todo o gene $\mathrm{H}$ de diferentes estirpes do CDV.

\section{AGRADECIMENTOS}

Os recursos financeiros utilizados para a realização desse trabalho foram obtidos nas seguintes agências de fomento a pesquisa: $\mathrm{CNPq}$, CAPES e Fundação Araucária (FAP/PR). Alfieri, A.A. é bolsista produtividade do $\mathrm{CNPq}$.

\section{REFERÊNCIAS BIBLIOGRÁFICAS}

ALTSCHUL, S.F.; GISH W.; MILLER W. et al. Basic Local Alignment Search Tool. J. Mol. Biol., v.215, p.403-410, 1990.

APPEL, M.J.G.; SUMMERS, B.A. Canine distemper: Current Status, 1999. Disponível em: $<$ http://www.ivis.org/> Acessado em: 13 mar. 2002.

APPEL, M.J.G.; YATES, R.A.; FOLEY, G.L. et al. Canine distemper epizootic in lions, tigers, and leopards in North America. J. Vet. Diagn. Invest., v.6, p.277-288, 1994.

BOLT, G.; JENSEN, T.D.; GOTTSCHALK, E. et al. Genetic diversity of the attachment $(\mathrm{H})$ protein gene of current field isolates of canine 
distemper virus. J. Gen. Virol., v.78, p.367-372, 1997.

BOOM, R.; SOL, C.J.A.; SALIMANS, M.M.M. et al. Rapid an simple method for purification of nucleic acids. J. Clin. Microbiol., v.28, p.495503, 1990

CHAMBERLAIN, R.W.; WANWAYI, H.; HOCKLEY, E. et al. Evidence for different lineages of rinderpest virus reflecting their geographic isolation. J. Gen. Virol., v.72, p.443447, 1993.

CHAPPUIS, G. Control of canine distemper. Vet. Microbiol., v.44, p.351-358, 1995.

DIALLO, A. Morbillivirus group: genome organization and proteins. Vet. Microbiol., v.23, p.155-163, 1990.

FRISK, A.L.; KONIG, M.; MORITZ, A. et al. Detection of canine distemper virus nucleoprotein RNA by reverse transcription-PCR using serum, whole blood, and cerebrospinhal fluid from dogs with distemper. J. Clin. Microbiol., v.37, p.3634-3643, 1999.

GEBARA, C.M.S.; WOSIACKI, S.R.; NEGRÃO, F.J. et al. Detecção do gene da nucleoproteína do vírus da cinomose canina por RT-PCR em urina de cães com sinais clínicos de cinomose. Arq. Bras. Med. Vet. Zootec., v.56, p.480-487, 2004b.

GEBARA, C.M.S.; WOSIACKI, S.R.; NEGRÃO, F.J. et al. Lesões histológicas no sistema nervoso central de cães com encefalite e diagnóstico molecular da infecção pelo vírus da cinomose canina. Arq. Bras. Med. Vet. Zootec., v.56, p.168-174, 2004a.

HAAS, L.; LIERMANN, H.; HARDER, T.C. et al. Analysis of the $\mathrm{H}$ gene, the central untranslated region and the proximal coding part of the $\mathrm{F}$ gene of wild-type and vaccine canine distemper viruses. Vet. Microbiol., v.69, p.15-18, 1999.

HAAS, L.; MARTENS, W.; GREISER-WILKE, I. et al. Analysis of the haemagglutinin gene of current wild-type canine distemper virus isolates from Germany. Virus Res., v. 48, p.165-171, 1997.
HARDER, T.C.; KLUSMEYER, K.; FREY, H.R. et al. Intertypic differentiation and detection of intratypic variants among canine and phocid morbilivirus isolates by kinetic neutralization using a novel imunoplaque assay. J. Virol. Methods, v.41, p.77-92, 1996.

HEADLEY, S.A.; GRAÇA, D.L. Canine distemper: epidemiological findings of 250 cases. Braz. J. Vet. Res. Anim. Sci., v.37, p.136140, 2000.

MORREL, V. Serengeti's big cats going to the dogs. Science, v.264, p.1664, 1994.

MOSHIZUKI, M.; HASHIMOTO, M.; HAGIWARA, S. et al. Genotypes of canine distemper virus determined by analysis of the hemagglutinin genes of recent isolates from dogs in Japan. J. Clin. Microbiol., v.37, p.2936-2942, 1999.

ÖRVELL, C.; BLIXENKRONE-MÖLLER, M.; SVANSSON, $\mathrm{V}$. et al. Immunological relationships between phocid and canine distemper virus studied with monoclonal antibodies. J. Gen. Virol., v.71, p.2085-2092, 1990.

PRINGLE, C.R. Virus taxonomy - 1999. The Universal System of Virus Taxonomy, updated to include the new proposals ratified by the International Committee on Taxonomy of Viruses 1998 (Suplem. 2). Arch. Virol., v.144, p.421-429, 1999.

RIMA, B.K.; EARLE, J.A.P.; YEO, R.P. et al. Temporal and geographical distribution of measles virus genotypes. J. Gen. Virol., v.76, p.1173-1180, 1995.

SAITO, T.B.; ALFIERI, A.A.; WOSIACKI, S.R. et al. Detection of canine distemper virus by reverse transcriptase-polymerase chain reaction in the urine of dogs with clinical signs of distemper encephalitis. Res. Vet. Sci., v.80, p.116-119, 2005.

TIPOLD, A. Diagnosis of inflamatory and infectious diseases of the central nervous system in dogs: a retrospective study. J. Vet. Intern. Med., v.9, p.304-314, 1995. 